\title{
PREVALENCE OF DRUG RESISTANCE AND VIRULENCE FEATURES IN Salmonella spp. ISOLATED FROM FOODS ASSOCIATED OR NOT WITH SALMONELLOSIS IN BRAZIL
}

Ruth Estela Gravato ROWLANDS(1), Christiane Asturiano RISTORI(1), Alice A. IKUNO(2), Maria Luisa BARBOSA(1), Miyoko JAKABI(1) \& Bernadette Dora Gombossy de Melo FRANCO(3)

\begin{abstract}
SUMMARY
Salmonella is the most common etiological agent of cases and outbreaks of foodborne diarrheal illnesses. The emergence and spread of Salmonella spp., which has become multi-drug resistant and potentially more pathogenic, have increased the concern with this pathogen. In this study, 237 Salmonella spp., associated or not with foodborne salmonellosis in Brazil, belonging mainly to serotype Enteritidis, were tested for antimicrobial susceptibility and the presence of the virulence genes $\operatorname{sp} C$, invA, sefA and pefA. Of the isolates, $46.8 \%$ were sensitive to all antimicrobials and $51.9 \%$ were resistant to at least one antimicrobial agent. Resistance to more than one antimicrobial agent was observed in $10.5 \%$ of the strains. The highest rates of resistance were observed for streptomycin (35.9\%) and nalidixic acid (16.9\%). No strain was resistant to cefoxitin, cephalothin, cefotaxime, amikacin, ciprofloxacin and imipenem. The $i n v A$ gene was detected in all strains. Genes $s p v C$ and $p e f A$ were found in $48.1 \%$ and $44.3 \%$ of strains, respectively. The gene sefA was detected in $31.6 \%$ of the strains and only among S. Enteritidis. Resistance and virulence determinants were detected in Salmonella strains belonging to several serotypes. The high rates of antibiotic-resistance in strains isolated from poultry products demonstrate the potential risk associated with the consumption of these products and the need to ensure good food hygiene practices from farm to table to reduce the spread of pathogens relevant to public health.
\end{abstract}

KEYWORDS: Salmonella spp.; Antimicrobial resistance; Virulence gene; Foodborne salmonellosis.

\section{INTRODUCTION}

Worldwide, Salmonella is the most common etiological agent of foodborne diarrheal illnesses ${ }^{18,26,45,46}$. There is an increasing concern with this pathogen due to the emergence and spread of antibiotic-resistant and potentially more pathogenic strains $\mathrm{s}^{37,39}$. The increase in resistant strains can be attributed to the inappropriate use of antimicrobials as therapeutic or prophylactic agents in human and veterinary medicine, as well as the use of growth promoters in animal production ${ }^{54}$. Studies suggest that the use of antibiotics in food animal production has contributed to the selection of resistant lineages transferable to humans via the food chain ${ }^{17}$. Antimicrobial-resistant Salmonella spp. have been isolated from different foods of animal origin around the world ${ }^{5,13,36,38,55,57}$.

The ability of Salmonella to cause disease can be attributed to an array of virulence genes located in the chromosome or in large virulenceassociated plasmids ${ }^{22}$. Gene invA in the Salmonella Pathogenicity Island ${ }^{33}$ codes for the production of proteins from the type III secretion system, related to the invasion of Salmonella into eukaryotic host cells ${ }^{49}$. Many Salmonella serotypes harbor virulence plasmids of varying sizes. The Salmonella plasmid virulence ( $s p v$ ) operon, which consists of five genes
( $s p v R A B C D)$, is important for the intracellular survival and replication of Salmonella, and contributes to the systemic phase of the illness ${ }^{22}$. There are many types of fimbriae that mediate Salmonella intestinal adhesion including type 1 fimbriae (Fim), long polar fimbriae (Lpf), aggregative fimbriae (Agf), plasmid-encoded fimbriae (Pef) and Salmonella Enteritidis fimbriae (Sef). The fim and agf operons are highly conserved among isolates of Salmonella, whereas the sef and pef operons are only found in certain serotypes ${ }^{2}$.

The objective of this study was to evaluate the prevalence of antimicrobial resistance and to detect the virulence -related genes among Salmonella spp. isolated from foods associated or not with foodborne salmonellosis.

\section{MATERIALS AND METHODS}

Salmonella spp.: The study included 237 randomly selected Salmonella spp. strains isolated from food sources between 1983 and 2007, belonging to the culture collection of Food Microbiology Laboratory of the Adolfo Lutz Institute, São Paulo, Brazil. The isolates belonged to 51 serotypes and most of them were $S$. Enteritidis (32\%).

(1) Food Microbiology Laboratory, Adolfo Lutz Institute, São Paulo, SP, Brazil

(2) Immunology Laboratory, Biologico Institute, São Paulo, SP, Brazil.

(3) Department of Food and Experimental Nutrition, Faculty of Pharmaceutical Sciences, University of Sao Paulo, Sao Paulo, SP, Brazil.

Correspondence to: Ruth E.G. Gravato Rowlands, Av. Dr. Arnaldo 355, Cerqueira Cesar, 01246-000 São Paulo, SP, Brasil. Phone: +55 11 3068.2932. E-mail: rrowlands@ usp.br 
ROWLANDS, R.E.G.; RISTORI, C.A.; IKUNO, A.A.; BARBOSA, M.L.; JAKABI, M. \& FRANCO, B.D.G.M. - Prevalence of drug resistance and virulence features in Salmonella spp. isolated from foods associated or not with salmonellosis in Brazil. Rev. Inst. Med. Trop. Sao Paulo, 56(6): 461-7, 2014.

Among the selected strains, 42 were isolated from foods associated with foodborne salmonellosis and 195 from food samples not associated with outbreaks or sporadic cases (Table 1). Among the strains from foods associated with salmonellosis, $14.3 \%$ were isolated from beef, $11.9 \%$ from poultry, $23.8 \%$ from confectionery, $21.4 \%$ from eggs and mayonnaise, $9.5 \%$ from water, $7.1 \%$ from vegetables, $2.4 \%$ from dairy products and $9.5 \%$ from other products. Regarding the strains obtained from foods not associated with salmonellosis, $27.2 \%$ were isolated from poultry, $29.7 \%$ from beef, $18 \%$ from pork, $11.3 \%$ from seafoods, $5.6 \%$ from condiments, $2 \%$ from milk and derivatives, $1.5 \%$ from eggs and mayonnaise, $1.5 \%$ from vegetables and $2.6 \%$ from other products.

Table 1

Number of isolates and serovars of Salmonella spp. included in the study

\begin{tabular}{|c|c|c|}
\hline \multirow[b]{2}{*}{ Serovar } & \multicolumn{2}{|c|}{ Number of isolates } \\
\hline & $\begin{array}{c}\text { Associated } \\
\text { with foodborne } \\
\text { salmonellosis } \\
\end{array}$ & $\begin{array}{c}\text { Not associated } \\
\text { with foodborne } \\
\text { salmonellosis } \\
\end{array}$ \\
\hline Enteritidis & 35 & 40 \\
\hline Typhimurium & 1 & 14 \\
\hline Agona & 1 & 9 \\
\hline Infantis & 1 & 8 \\
\hline Brandenburg & 1 & 7 \\
\hline Saintpaul & 1 & 2 \\
\hline I 6,7:r:- & 1 & 3 \\
\hline Sandiego & 1 & 3 \\
\hline Panama & -- & 11 \\
\hline Anatum & -- & 12 \\
\hline Bredeney & -- & 7 \\
\hline Heidelberg & -- & 6 \\
\hline $\begin{array}{l}\text { Ohio, Oranienburg and } \\
\text { Schwarzengrund }\end{array}$ & -- & 5 each \\
\hline $\begin{array}{l}\text { Madelia, Mbandaka, I 4, 5, 12: i: - } \\
\text { and London, }\end{array}$ & -- & 4 each \\
\hline Hadar and Derby & -- & 3 each \\
\hline $\begin{array}{l}\text { Senftenberg, Cerro, IV 43:Z4, } \\
\text { Z24:-, Glostrup, Give, I 4, 12: i:- and } \\
\text { Rubislaw }\end{array}$ & -- & 2 each \\
\hline $\begin{array}{l}\text { Muenster, I 4, 5, 12: b: -, Javiana, } \\
\text { 3, 10: Z: -, Emek, Muenchen, } \\
\text { Saphra, Levingstone, I 6, 8: E, H: } \\
\text {-, Lexington, Brandenlsing, 1,4, } \\
\text { 5, 12, Berta, Poona, I 3, 10: - :1,6, } \\
\text { Abaetetuba, I 13, 23: Z: -, Tenessee, I } \\
\text { 6,8:Z10:-, Newport, Paratyphi B and } \\
\text { Pomona }\end{array}$ & 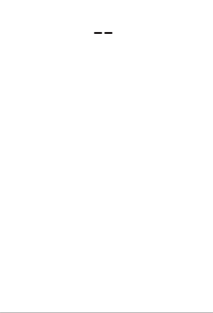 & 1 each \\
\hline Total & 42 & 195 \\
\hline
\end{tabular}

Determination of the antimicrobial susceptibility profile: The strains were tested for antibiotic resistance by the plate disk diffusion method, according to the Clinical and Laboratory Standards Institute ${ }^{8}$. The following disks (Oxoid, Basingstoke, UK) were included in the test: ampicillin $(10 \mu \mathrm{g})$, cefoxitin $(30 \mu \mathrm{g})$, cephalothin $(30 \mu \mathrm{g})$, cefotaxime $(30 \mu \mathrm{g})$, imipenem $(10 \mu \mathrm{g})$, chloramphenicol $(30 \mu \mathrm{g})$, amikacin $(30 \mu \mathrm{g})$, gentamicin $(10 \mu \mathrm{g})$, kanamycin $(30 \mu \mathrm{g})$, streptomycin $(10 \mu \mathrm{g})$, nalidixic acid $(30 \mu \mathrm{g})$, ciprofloxacin $(5 \mu \mathrm{g})$, tetracycline $(30 \mu \mathrm{g})$, trimethoprimsulphamethoxazole $(1.25 / 23.75 \mu \mathrm{g})$ and sulphonamides $(300 \mu \mathrm{g})$. Escherichia coli ATCC 25922 was used for quality control. Results were interpreted as recommended by CLSI (2012b) ${ }^{9}$.

Investigation of virulence genes: The virulence genes pefA, invA, sefA and $s p v C$ were investigated as described by CORTEZ et al. $(2006)^{10}$ with some modifications. DNA was extracted from the cultures using the Wizard® Genomic DNA Purification System kit (Promega) following the manufacturer's instructions. The pefA gene was investigated by singleplex PCR with the primers pefA-1 (5'- TTCCATTATTGCACTGGGTG-3') and pefA-2 (5'-AAGCCACTGCGAAAGATGCC-3') ${ }^{25}$. The genes $i n v A$, sefA and $s p v C$ were amplified by multiplex PCR, with the following primers: invA-1 (5'-TTGTTACGGCTATTTTGACCA-3') and invA-2 (5' -CTGACTGCTACCTTGCTGATG-3' $)^{47}$; sefA-3 (5' - GCAGCGGTTACTATTGCAGC-3') and sefA4 ( $5^{\prime}$ - TGTGACAGGGACATTTAGCG-3' $)^{56} ; s p v C-1$ (5'-CGGAAATACCATCTACAAATA-3') and $s p v C-2$ (5'-CCCAAACCCATACTTACTCTG-3') ${ }^{47}$.

Singleplex PCR was performed in a reaction volume of $25 \mu \mathrm{L}$ containing PCR reaction buffer $(50 \mathrm{mM} \mathrm{KCl}, 10 \mathrm{mM}$ Tris- $\mathrm{HCl}, 2.5 \mathrm{mM}$ $\left.\mathrm{MgCl}_{2}, \mathrm{pH} 8.3\right), 200 \mu \mathrm{M} d \mathrm{dTP}, 3 \mathrm{mM} \mathrm{MgCl}, 0.1 \mu \mathrm{M}$ pefA primers, 2.5 $\mathrm{U}$ Taq DNA polymerase, and $2 \mu \mathrm{L}$ DNA template. Amplification was carried out in an automatic thermocycler (GeneAmp PCR System 2400, Perkin Elmer) with the following cycles: $94^{\circ} \mathrm{C}$ for two minutes, followed by 35 cycles of $94^{\circ} \mathrm{C}$ for 30 seconds, $50^{\circ} \mathrm{C}$ for 45 seconds and $72^{\circ} \mathrm{C}$ for one minute, and a final elongation at $72^{\circ} \mathrm{C}$ for seven minutes. The samples were stored at $4{ }^{\circ} \mathrm{C}$ until electrophoresis. The same conditions were used for the multiplex PCR, except that primers were used in the following concentrations: $0.2 \mu \mathrm{M}$ invA, $0.5 \mu \mathrm{M}$ sefA and $0.5 \mu \mathrm{M} s p v C$; in addition, annealing temperature was $55^{\circ} \mathrm{C}$ rather than $50^{\circ} \mathrm{C}$. Electrophoresis of amplified products was carried out using $1.5 \%$ agarose gel in TAE running buffer (40 mM Tris-acetate, $1 \mathrm{mM}$ EDTA, $\mathrm{pH}$ 8.00) containing $0.5 \mu \mathrm{g} /$ $\mathrm{mL}$ of ethidium bromide. The amplified DNA fragments were visualized under UV light. $S$. Enteritidis ATCC 13076 and $S$. Typhimurium ATCC 14028 were used as positive controls.

\section{RESULTS AND DISCUSSION}

Antimicrobial susceptibility tests indicated that $51.9 \%$ of the strains were resistant to at least one antimicrobial agent and that $10.5 \%$ were resistant to more than one antimicrobial. Resistant strains were more common in foods not associated with foodborne salmonellosis (55.9\%) than in those related to salmonellosis (33.3\%). The resistant Salmonella spp. were grouped in 14 different antimicrobial resistance profiles (Table 2). Resistance was observed in 35 serotypes, mainly in $S$. Infantis (88.9\%), S. Typhimurium (80\%), S. Enteritidis (58.7\%), S. Anatum (50\%) and $S$. Agona (40\%).

All Salmonella spp. were susceptible to cefoxitin, cephalothin, cefotaxime, amikacin, ciprofloxacin and imipenem. As for other antibiotics, resistance to streptomycin prevailed in strains associated with salmonellosis (16.7\%) in comparison with those not associated with salmonellosis (39\%). Resistance to streptomycin was observed in strains belonging to 33 different serotypes. Similar rates were reported in Spain ${ }^{50}$, the United States ${ }^{40}$ and Brazil ${ }^{29}$. According to PEIRANO et al. 


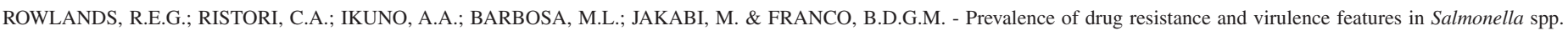
isolated from foods associated or not with salmonellosis in Brazil. Rev. Inst. Med. Trop. Sao Paulo, 56(6): 461-7, 2014.

Table 2

Antimicrobial resistance among Salmonella spp. strains isolated from foods associated and not associated with foodborne salmonellosis

\begin{tabular}{lcc}
\hline Resistance to & $\begin{array}{c}\text { Associated } \\
\text { with foodborne } \\
\text { salmonellosis }\end{array}$ & $\begin{array}{c}\text { Not associated } \\
\text { with foodborne } \\
\text { salmonellosis }\end{array}$ \\
\hline STR & $2(4.8 \%)$ & $57(29.2 \%)$ \\
NAL & $7(16.7 \%)$ & $28(14.3 \%)$ \\
TET & -- & $3(1.5 \%)$ \\
AMP & -- & $1(0.5 \%)$ \\
GEN+STR & $1(2.4 \%)$ & $5(2.6 \%)$ \\
GEN+KAN & -- & $1(0.5 \%)$ \\
TET+STR & -- & $6(3.1 \%)$ \\
SSS+STR & -- & $2(1.0 \%)$ \\
GEN+KAN+STR & $1(2.4 \%)$ & -- \\
GEN+NAL+STR & $2(4.8 \%)$ & $1(0.5 \%)$ \\
TET+SSS+STR & -- & $2(1.0 \%)$ \\
TET+KAN+STR & -- & $1(0.5 \%)$ \\
TET+NAL+CHL+STR & -- & $2(1.0 \%)$ \\
AMP+STX+SSS+STR & $1(2.4 \%)$ & -- \\
\hline Number of resistant strains & $14(33.3 \%)$ & $109(55.9 \%)$ \\
\hline AMP
\end{tabular}

AMP, ampicillin; FOX, cefoxitin; CEF, cephalothin; CTX, cefotaxime; CHL, chloramphenicol; TET, tetracycline; AK, amikacin; GEN, gentamicin; STX, trimethoprim-sulphamethoxazole; CIP, ciprofloxacin; NAL, nalidixic acid; IPM, imipenem; KAN, kanamycin; SSS, sulphonamides; STR, streptomycin.
$(2006)^{43}$, resistance to streptomycin might be related to co-selection, since the therapeutic use of this antibiotic in human and veterinary medicine has declined in recent years.

Among nalidixic acid resistant strains, $21.5 \%$ were associated with salmonellosis and $15.9 \%$ of them were not associated with salmonellosis. Resistance to nalidixic acid was detected in serotypes Enteritidis, Typhimurium and Infantis, and only in strains isolated from poultry products. Fluoroquinolones are extensively used as therapeutic drugs in veterinary medicine and the use of these compounds can select for mutant Salmonella strains resistant to nalidixic acid or with reduced susceptibility to fluoroquinolones ${ }^{20,21,30,48}$. Resistant strains to nalidixic acid were detected mainly from the beginning of 2000. Before that, only one strain isolated in 1993 was resistant to this antibiotic (Table 5). In Europe, the occurrence of resistance to nalidixic acid in $S$. Enteritidis strains of human origin almost tripled between 2000 and 2004, rising from $10 \%$ to $26 \%{ }^{35}$. In Brazil, OLIVEIRA et al. $(2005)^{41}$ evaluated 31 strains of $S$. Enteritidis isolated from food involved in outbreaks in the state of Rio Grande do Sul from 1995 to 1997 and verified that only 3.2\% of the strains were resistant to nalidixic acid. However, another study carried out by OLIVEIRA et al. $(2006)^{42}$ with $79 \mathrm{~S}$. Enteritidis strains isolated from outbreaks in this same region between 2001 and 2002 found high resistance rates $(21.5 \%)$, which are similar to this study's findings for strains associated with food poisoning.

Concerning resistance to tetracycline, gentamicin, sulphonamides, kanamycin, ampicilin, chloramfenicol and trimethoprimsulphamethoxazole, the prevalence of resistant Salmonella spp. was low - below $6 \%$. Although the use of tetracycline as a growth promoter has been banned in Brazil since 1998, this antimicrobial agent remains

Table 3

Prevalence of the $s p v C$, sefA and pefA genes among Salmonella spp. strains isolated from foods associated and not associated with foodborne salmonellosis

\begin{tabular}{|c|c|c|c|c|c|c|c|c|}
\hline \multirow{3}{*}{ Serovar } & \multicolumn{4}{|c|}{ Strains associated with food poisoning } & \multicolumn{4}{|c|}{ Strains not associated with food poisoning } \\
\hline & \multirow{2}{*}{$\mathrm{n}$} & \multicolumn{3}{|c|}{ positive } & \multirow{2}{*}{$\mathrm{n}$} & \multicolumn{3}{|c|}{ positive } \\
\hline & & $\operatorname{spv} C$ & sefA & pefA & & $\operatorname{spvC}$ & sefA & pefA \\
\hline S. Enteritidis & 35 & $33(94.3 \%)$ & $35(100 \%)$ & $34(97.1 \%)$ & 40 & $35(87.5 \%)$ & $40(100 \%)$ & $38(95 \%)$ \\
\hline$S$. Typhimurium & 1 & $1(100 \%)$ & 0 & $1(100 \%)$ & 14 & $10(71.4 \%)$ & 0 & $9(64.3 \%)$ \\
\hline S. Agona & 1 & 0 & 0 & 0 & 9 & $3(33.3 \%)$ & 0 & $1(11.1 \%)$ \\
\hline$S$. Infantis & 1 & 0 & 0 & 0 & 8 & $3(37.5 \%)$ & 0 & $4(50 \%)$ \\
\hline$S$. Brandenburg & 1 & 0 & 0 & 0 & 7 & $3(42.8 \%)$ & 0 & $3(42.8 \%)$ \\
\hline S. Saintpaul & 1 & 0 & 0 & 0 & 2 & 0 & 0 & 0 \\
\hline S. enterica I 6,7:r:- & 1 & 0 & 0 & 0 & 4 & $1(25 \%)$ & 0 & $1(25 \%)$ \\
\hline$S$. Sandiego & 1 & 0 & 0 & 0 & 3 & 0 & 0 & 0 \\
\hline S. Panama & 0 & n.a. & n.a. & n.a. & 11 & $7(63.6 \%)$ & 0 & 0 \\
\hline S. Anatum & 0 & n.a. & n.a. & n.a. & 12 & $9(75 \%)$ & 0 & $2(16.7 \%)$ \\
\hline$S$. Hadar & 0 & n.a. & n.a. & n.a. & 3 & $2(66.7 \%)$ & 0 & $3(100 \%)$ \\
\hline$S$. Heidelberg & 0 & n.a. & n.a. & n.a. & 6 & $1(16.7 \%)$ & 0 & $1(16.7 \%)$ \\
\hline S. enterica I 4, 5, 12:i:- & 0 & n.a. & n.a. & n.a. & 4 & 0 & 0 & $2(50 \%)$ \\
\hline$S$. Bredeney & 0 & n.a. & n.a. & n.a. & 7 & $5(71.4 \%)$ & 0 & $5(71.4 \%)$ \\
\hline S. enterica I 4,12:i:- & 0 & n.a. & n.a. & n.a. & 2 & $1(50 \%)$ & 0 & $1(50 \%)$ \\
\hline
\end{tabular}

n.a. = non applicable 
ROWLANDS, R.E.G.; RISTORI, C.A.; IKUNO, A.A.; BARBOSA, M.L.; JAKABI, M. \& FRANCO, B.D.G.M. - Prevalence of drug resistance and virulence features in Salmonella spp. isolated from foods associated or not with salmonellosis in Brazil. Rev. Inst. Med. Trop. Sao Paulo, 56(6): 461-7, 2014.

one of the most frequently used therapeutic drugs in animal production ${ }^{41}$ thus contributing to the high levels of resistance to this antimicrobial ${ }^{32}$. In this survey, resistance to this antibiotic was low (5.9\%) whereby eight strains were isolated in years prior to the prohibition and six were isolated in 2002 (Table 5) and found in strains belonging to serotypes Typhimurium, Bradenburg, Hadar, I 4, 5, 12: i:-, Derby, Bredeney and I 6,8: Z10:-. The low resistance observed for the sulphonamides is surprising, since other Brazilian studies have reported a high frequency of resistance to this antibiotic in Salmonella $a^{3,23,36}$.

Regarding $S$. Enteritidis, the serotype with the highest prevalence in humans in Brazil ${ }^{19}, 31.4 \%(11 / 35)$ of the strains associated with foodborne salmonellosis and $82.5 \%$ (33/40) of the strains not involved in salmonellosis were resistant to one or more antimicrobial agents. The higher prevalence of resistance among strains not involved in salmonellosis cases or outbreaks may be related to food sources. Among the strains not associated with foodborne salmonellosis, $81.8 \%$ were isolated from poultry and related products, whereas among the strains involved in salmonellosis, only $21.4 \%$ were obtained from these products. In Brazil, resistant $S$. Enteritidis has been frequently isolated from foods of animal origin, mainly poultry-related products ${ }^{1,16,36,41,52}$. Concerning nalidixic acid, a total of $70 \%$ of strains not associated with salmonellosis were resistant to this antibiotic, while $25.7 \%$ of the strains involved in salmonellosis presented this phenotype, certainly due to the higher number of strains not associated with salmonellosis isolated from poultry and poultry-related products. On the other hand, similar resistance to streptomycin and gentamycin was observed in strains associated or not with salmonellosis: $11.4 \%$ and $15 \%$ for streptomycin, respectively, and $11.4 \%$ and $12.5 \%$ for gentamycin, respectively.

The virulence gene inv $A$ was detected in all strains, which is consistent with the findings from previous reports ${ }^{7,28,40}$. InvA is conserved among Salmonella serotypes and is a useful marker for molecular detection of this pathogen by $\mathrm{PCR}^{15,31}$.

The genes spvC, sefA and pefA were observed in $48.1 \%, 31.6 \%$ and $44.3 \%$ of the strains, respectively. Studies have shown a heterogeneous distribution of these virulence factors in Salmonella isolated from different origins $\mathrm{s}^{4,53,58}$.

The $s p v C$ gene has an important role in systemic infection of Salmonella ${ }^{24,34}$ and in the present survey this gene was found in $80.9 \%$ (34/42) and 41\% (80/195) of the strains associated and not associated with foodborne salmonellosis, respectively (Table 3 ). The spv operon is located in virulence plasmids and limited to specific serotypes (i.e. Enteritidis, Typhimurium, Dublin, Cholerae-suis, Gallinarum, Pullorum and Abortusovis $)^{44}$. Among the strains associated with salmonellosis, the serotypes that commonly have plasmids ( $S$. Enteritidis and $S$. Typhimurium) corresponded to $86 \%$ of the analyzed strains, whereas among those not involved in salmonellosis, these two serotypes corresponded to only $27.7 \%$ of the strains.

The sefA gene was detected in $83.3 \%$ (35/42) and 20.5\% (40/195) of the strains associated and not associated with salmonellosis, respectively. This gene was only present in $S$. Enteritidis (Table 3 ), which is an expected result since the genes of the sef operon $(\operatorname{sef} A B C D)$ are restricted to the serotypes of serogroup O:9, which include $S$. Enteritidis, $S$. Typhi, $S$. Dublin, $S$. Berta, $S$. Gallinarum and others ${ }^{14}$. Due to the specificity of the sef gene, it has been used for the molecular identification of Salmonella Enteritidis ${ }^{10,11,12}$.

The pefA gene was present in $83.3 \%$ (35/42) and 35.9\% (70/195) of the strains associated and not associated with foodborne salmonellosis, respectively (Table 3). Like the $s p v C$ gene, pefA is located in virulence plasmids, and limited to certain serotypes such as Enteritidis, Choleraesuis and Typhimurium ${ }^{2}$.

All $S$. Enteritidis isolated from samples associated or not with foodborne salmonellosis contained the invA and sefA genes. The prevalence of invA and sefA genes in strains associated $(94.3 \%$ and $97.1 \%$, respectively) and not associated with salmonellosis $(87.5 \%$ and $95 \%$, respectively) was similar. Regarding these four genes, $S$. Enteritidis strains evaluated in this study were grouped into three profiles (Table 4 ), with a predominance of strains in the P1 profile (presence of the four virulence genes). These results highlight the pathogenic potential of $S$. Enteritidis, which is the major serotype associated with human salmonellosis in Brazil ${ }^{19}$.

This survey illustrates the occurrence of antibiotic-resistance and a wide distribution of virulence genes in Salmonella spp. regardless of their association with foodborne salmonellosis. Resistance and virulence determinants were detected in strains belonging to several serotypes. The high rates of antibiotic-resistance in strains isolated from poultry demonstrate the potential risk associated with the consumption of these products and the need to ensure good food hygiene practices from farm to table in order to reduce the spread of antibiotic-resistant microorganisms from animals to humans.

The development of antimicrobial resistance in zoonotic bacteria, such as non-typhoidal Salmonella, constitutes a public health risk with many consequences for human health. As bacteria become increasingly more resistant to drugs of clinical importance, there is an increased risk of treatment failure due to limited therapeutic choices ${ }^{39}$. Furthermore, antibiotic-resistance and virulence determinants may be present in the

Table 4

Virulence profile of Salmonella Enteritidis strains associated and not associated with foodborne salmonellosis

\begin{tabular}{|c|c|c|c|c|c|c|}
\hline \multirow{2}{*}{ Profile } & \multicolumn{2}{|c|}{ Number of isolates } & \multicolumn{4}{|c|}{ Genes } \\
\hline & Associated with food poisoning & Not associated with food poisoning & $s p v C$ & invA & sefA & pefA \\
\hline P1 & $33(94.3 \%)$ & $35(87.5 \%)$ & + & + & + & + \\
\hline $\mathrm{P} 2$ & $1(2.8 \%)$ & $2(5 \%)$ & - & + & + & + \\
\hline P3 & $1(2.8 \%)$ & $3(7.5 \%)$ & - & + & + & - \\
\hline
\end{tabular}




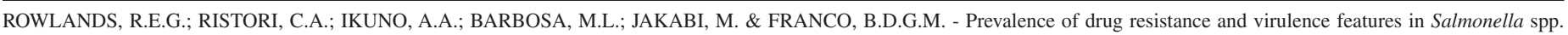
isolated from foods associated or not with salmonellosis in Brazil. Rev. Inst. Med. Trop. Sao Paulo, 56(6): 461-7, 2014.

Table 5

Frequency (\%) of resistance to the 15 antimicrobials tested by year of isolation for Salmonella spp. strains

\begin{tabular}{|c|c|c|c|c|c|c|c|c|c|c|c|c|c|c|c|c|c|c|c|c|c|c|c|}
\hline \multirow{2}{*}{$\begin{array}{l}\text { Anti- } \\
\text { biotics }\end{array}$} & \multicolumn{23}{|c|}{$\begin{array}{c}\text { Year } \\
\text { (number of isolates) }\end{array}$} \\
\hline & $\begin{array}{l}1983 \\
(\mathrm{n}=1)\end{array}$ & $\begin{array}{l}1984 \\
(n=2)\end{array}$ & $\begin{array}{c}1986 \\
(\mathrm{n}=13) \\
\end{array}$ & $\begin{array}{c}1987 \\
(\mathrm{n}=2)\end{array}$ & $\begin{array}{l}1988 \\
(n=3)\end{array}$ & $\begin{array}{c}1990 \\
(n=10)\end{array}$ & $\begin{array}{l}1991 \\
(\mathrm{n}=8)\end{array}$ & $\begin{array}{c}1992 \\
(n=19)\end{array}$ & $\begin{array}{c}1993 \\
(n=37) \\
\end{array}$ & $\begin{array}{l}1994 \\
(\mathrm{n}=4)\end{array}$ & $\begin{array}{l}1995 \\
(n=5)\end{array}$ & $\begin{array}{l}1996 \\
(\mathrm{n}=5)\end{array}$ & $\begin{array}{c}1997 \\
(\mathrm{n}=16)\end{array}$ & $\begin{array}{l}1998 \\
(\mathrm{n}=3)\end{array}$ & $\begin{array}{l}1999 \\
(n=6)\end{array}$ & $\begin{array}{c}2000 \\
(\mathrm{n}=12) \\
\end{array}$ & $\begin{array}{c}2001 \\
(n=13)\end{array}$ & $\begin{array}{c}2002 \\
(n=29) \\
\end{array}$ & $\begin{array}{l}2003 \\
(n=7) \\
\end{array}$ & $\begin{array}{c}2004 \\
(\mathrm{n}=31) \\
\end{array}$ & $\begin{array}{l}2005 \\
(\mathrm{n}=2)\end{array}$ & $\begin{array}{l}2006 \\
(\mathrm{n}=3)\end{array}$ & $\begin{array}{l}2007 \\
(n=6)\end{array}$ \\
\hline AMP & 0 & 0 & 0 & 0 & 0 & 0 & 0 & 0 & 0 & 0 & 0 & 0 & 0 & 0 & 0 & 0 & 0 & 3.4 & 0 & 0 & 0 & 0 & 16.7 \\
\hline FOX & 0 & 0 & 0 & 0 & 0 & 0 & 0 & 0 & 0 & 0 & 0 & 0 & 0 & 0 & 0 & 0 & 0 & 0 & 0 & 0 & 0 & 0 & 0 \\
\hline CEF & 0 & 0 & 0 & 0 & 0 & 0 & 0 & 0 & 0 & 0 & 0 & 0 & 0 & 0 & 0 & 0 & 0 & 0 & 0 & 0 & 0 & 0 & 0 \\
\hline CTX & 0 & 0 & 0 & 0 & 0 & 0 & 0 & 0 & 0 & 0 & 0 & 0 & 0 & 0 & 0 & 0 & 0 & 0 & 0 & 0 & 0 & 0 & 0 \\
\hline CHL & 0 & 0 & 0 & 0 & 0 & 0 & 0 & 0 & 0 & 0 & 0 & 0 & 0 & 0 & 0 & 0 & 0 & 6.7 & 0 & 0 & 0 & 0 & 0 \\
\hline TET & 0 & 0 & 0 & 33.3 & 0 & 10 & 0 & 5.3 & 8.3 & 0 & 0 & 0 & 6.25 & 0 & 0 & 0 & 0 & 20.7 & 0 & 0 & 0 & 0 & 0 \\
\hline $\mathrm{AK}$ & 0 & 0 & 0 & 0 & 0 & 0 & 0 & 0 & 0 & 0 & 0 & 0 & 0 & 0 & 0 & 0 & 0 & 0 & 0 & 0 & 0 & 0 & 0 \\
\hline GEN & 0 & 0 & 0 & 0 & 0 & 0 & 0 & 0 & 0 & 0 & 0 & 0 & 25 & 0 & 0 & 8.3 & 15.4 & 13.8 & 0 & 0 & 0 & 0 & 0 \\
\hline STX & 0 & 0 & 0 & 0 & 0 & 0 & 0 & 0 & 0 & 0 & 0 & 0 & 0 & 0 & 0 & 0 & 0 & 0 & 0 & 0 & 0 & 0 & 16.7 \\
\hline CIP & 0 & 0 & 0 & 0 & 0 & 0 & 0 & 0 & 0 & 0 & 0 & 0 & 0 & 0 & 0 & 0 & 0 & 0 & 0 & 0 & 0 & 0 & 0 \\
\hline NAL & 0 & 0 & 0 & 0 & 0 & 0 & 0 & 0 & 2.8 & 0 & 0 & 0 & 0 & 0 & 0 & 25 & 0 & 20.7 & 57.1 & 74.2 & 50 & 33.3 & 16.7 \\
\hline IPM & 0 & 0 & 0 & 0 & 0 & 0 & 0 & 0 & 0 & 0 & 0 & 0 & 0 & 0 & 0 & 0 & 0 & 0 & 0 & 0 & 0 & 0 & 0 \\
\hline KAN & 0 & 0 & 0 & 0 & 0 & 0 & 0 & 5.3 & 0 & 0 & 0 & 0 & 0 & 0 & 0 & 8.3 & 7.7 & 0 & 0 & 0 & 0 & 0 & 0 \\
\hline SSS & 0 & 0 & 0 & 0 & 0 & 0 & 25 & 0 & 2.8 & 0 & 0 & 0 & 6.25 & 0 & 0 & 0 & 0 & 0 & 0 & 0 & 0 & 0 & 16.7 \\
\hline STR & 0 & 100 & 38.5 & 66.6 & 0 & 50 & 50 & 57.9 & 41.7 & 0 & 0 & 20 & 37.5 & 33.3 & 16.7 & 33.3 & 23.1 & 41.4 & 14.3 & 12.9 & 0 & 66.7 & 66.7 \\
\hline
\end{tabular}

AMP, ampicillin; FOX, cefoxitin; CEF, cephalothin; CTX, cefotaxime; CHL, chloramphenicol; TET, tetracycline; AK, amikacin; GEN, gentamicin; STX, trimethoprimsulphamethoxazole; CIP, ciprofloxacin; NAL, nalidixic acid; IPM, imipenem; KAN, kanamycin; SSS, sulphonamides; STR, streptomycin.

same plasmid, which may be selected by antibiotic pressure ${ }^{6,27,37}$ resulting in increased systemic infections and hospitalizations of patients infected with resistant non-typhoid Salmonella ${ }^{51}$.

\section{RESUMO}

\section{Prevalência de resistência antimicrobiana e características de virulência em Salmonella spp. isoladas de alimentos associados ou não com salmonelose no Brasil}

Salmonella é o agente etiológico mais comumente envolvido em casos e surtos de doenças diarréicas de origem alimentar. A preocupação com este patógeno é, ainda, maior quando se verifica o surgimento e a disseminação de cepas multirresistentes e potencialmente mais patogênicas. Neste estudo, 237 cepas Salmonella spp., associadas ou não com casos ou surtos de salmonelose e pertencentes, principalmente, ao sorovar Enteritidis, foram avaliadas quanto ao perfil de susceptibilidade antimicrobiana e presença dos genes de virulência $s p v \mathrm{C}$, invA, sef A e pefA. Entre as cepas avaliadas, $46,8 \%$ foram sensíveis a todos os agentes antimicrobianos e $51,9 \%$ foram resistentes a pelo menos uma droga. Multirresistência foi observada em 10,5\% das cepas. As maiores taxas de resistência foram observadas para estreptomicina $(35,9 \%)$ e ácido nalidíxico (16,9\%). Não foram detectadas cepas resistentes à cefoxitina, cefalotina, cefotaxima, amicacina, ciprofloxaxina e imipenem. O gene invA foi detectado em todas as cepas de Salmonella. Os genes spvC e pefA foram encontrados em $48,1 \%$ e $44,3 \%$ das cepas, respectivamente. $\mathrm{O}$ gene sefA foi detectado em $31,6 \%$ das cepas, estando presente somente entre as cepas de $S$. Enteritidis. Resistência antimicrobiana e marcadores de virulência foram detectados em cepas de Salmonella pertencentes a diversos sorovares. A alta taxa de resistência antimicrobiana verificada em cepas isoladas de frangos e derivados demonstra o potencial risco associado ao consumo destes produtos e a necessidade de se assegurar boas práticas de higiene em toda cadeia produtiva para reduzir a disseminação de patógenos relevantes para a saúde pública.

\section{ACKNOWLEDGEMENTS}

The authors would like to thank FAPESP (Fundação de Amparo à Pesquisa do Estado de São Paulo), CNPq (Conselho Nacional de Desenvolvimento Cientifico e Tecnológico) and CAPES (Coordenação de Aperfeiçoamento de Pessoal de Nível Superior) for their financial support.

\section{REFERENCES}

1. Álvarez-Fernández E, Alonso-Calleja C, García-Fernández C, Capita R. Prevalence and antimicrobial resistance of Salmonella serotypes isolated from poultry in Spain: comparison between 1993 and 2006. Int J Food Microbiol. 2012;153:281-7.

2. Bäumler AJ, Gilde AJ, Tsolis RM, Van Der Velden AW, Ahmer BM, Heffron F Contribution of horizontal gene transfer and deletion events to development of distinctive patterns of fimbrial operons during evolution of Salmonella serotypes. J Bacteriol. 1997;179:317-22.

3. Bessa MC, Michael GB, Canu N, Canal CW, Cardoso M, Rabsch W, et al. Phenotypic and genetic characterization of Salmonella enterica subsp. enterica serovar Typhimurium isolated from pigs in Rio Grande do Sul, Brazil. Res Vet Sci. 2007;83:302-10.

4. Bolton DJ, O'Neill CJ, Fanning S. A preliminary study of Salmonella, verocytotoxigenic Escherichia coli/Escherichia coli $\mathrm{O} 157$ and Campylobacter on four mixed farms. Zoonoses Public Health. 2012;59:217-28.

5. Bosilevac JM, Guerini MN, Kalchayanand N, Koohmaraie M. Prevalence and characterization of Salmonellae in commercial ground beef in the United States. Appl Environ Microbiol. 2009;75:1892-900.

6. Chu C, Chiu CH. Evolution of the virulence plasmids of non-typhoid Salmonella and its association with antimicrobial resistance. Microbes Infect. 2006; 8:1931-6. 
ROWLANDS, R.E.G.; RISTORI, C.A.; IKUNO, A.A.; BARBOSA, M.L.; JAKABI, M. \& FRANCO, B.D.G.M. - Prevalence of drug resistance and virulence features in Salmonella spp. isolated from foods associated or not with salmonellosis in Brazil. Rev. Inst. Med. Trop. Sao Paulo, 56(6): 461-7, 2014.

7. Chuanchuen R, Ajariyakhajorn K, Koowatananukul C, Wannaprasat W, Khemtong S, Samngamnim S. Antimicrobial resistance and virulence genes in Salmonella enterica isolates from dairy cows. Foodborne Pathog Dis. 2010;7:63-9.

8. CLSI - Clinical and Laboratory Standards Institute. Performance standards for antimicrobial disk susceptibility tests: approved standard. $11^{\text {th }}$ ed. Wayne: CLSI Publication M2-A11; 2012a.

9. CLSI. Clinical and Laboratory Standards Institute. Performance standards for antimicrobial susceptibility testing: twenty-first informational supplement. Wayne: CLSI Publication M100-S21; 2012b.

10. Cortez AL, Carvalho AC, Ikuno AA, Bürger KP, Vidal-Martins AM. Identification of Salmonella spp. isolates from chicken abattoirs by multiplex-PCR. Res Vet Sci. 2006;81:340-4.

11. Crăciunaş C, Keul AL, Flonta M, Cristea M. DNA-based diagnostic tests for Salmonella strains targeting hilA, agfA, $s p v C$ and sef genes. J Environ Manage. 2012;95:S15-8.

12. Day JB, Basavanna U, Sharma SK. Development of a cell culture method to isolate and enrich Salmonella enterica serotype Enteritidis from shell eggs for subsequent detection by real-time PCR. Appl Environ Microbiol. 2009;75:5321-7.

13. Deng X, Ran L, Wu S, Ke B, He D, Yang X, et al. Laboratory-based surveillance of nontyphoidal Salmonella infections in Guangdong Province, China. Foodborne Pathog Dis. 2012;9:305-12.

14. Doran JL, Collinson SK, Clouthier SC, Cebula TA, Koch WH, Burian J, et al. Diagnostic potential of sefA DNA probes to Salmonella enteritidis and certain other O-serogroup D1 Salmonella serovars. Mol Cell Probes. 1996;10:233-46.

15. D'Souza DH, Critzer FJ, Golden DA. Real-time reverse-transcriptase polymerase chain reaction for the rapid detection of Salmonella using invA primers. Foodborne Pathog Dis. 2009;6:1097-106.

16. Duarte DAM, Ribeiro AR, Vasconcelos AMM, Santos SB, Silva JVD, de Andrade PL, et al. Occurrence of Salmonella spp. in broiler chicken carcasses and their susceptibility to antimicrobial agents. Braz J Microbiol. 2009;40:569-73.

17. EFSA. European Food Safety Authority. Scientific opinion of the panel on biological hazards on a request from the European Food Safety Authority on foodborne antimicrobial resistance as a biological hazard. EFSA J. 2008;765:1-87.

18. EFSA. European Food Safety Authority. The European Union summary report on trends and sources of zoonoses, zoonotic agents and foodborne outbreaks in 2009. EFSA J. 2011;9:2090-477.

19. Fernandes SA, Tavechio AT, Ghilardi AC, Dias AM, Almeida IA, Melo LC. Salmonella serovars isolated from humans in São Paulo state, Brazil, 1996-2003. Rev Inst Med Trop Sao Paulo. 2006;48:179-84.

20. Ferrari R, Galiana A, Cremades R, Rodriguez JC, Magnani M, Tognim MC, et al. Plasmid-mediated quinolone resistance by genes qnrA1 and qnrB19 in Salmonella strains isolated in Brazil. J Infect Dev Ctries. 2011;5:496-8.

21. Ferrari R, Galiana A, Cremades R, Rodríguez JC, Magnani M, Tognim MC, et al. Plasmidmediated quinolone resistance (PMQR) and mutations in the topoisomerase genes of Salmonella enterica strains from Brazil. Braz J Microbiol. 2013;44:651-6.

22. Fluit AC. Towards more virulent and antibiotic-resistant Salmonella? FEMS Immunol Med Microbiol. 2005;43:1-11.

23. Ghilardi AC, Tavechio AT, Fernandes SA. Antimicrobial susceptibility, phage types, and pulsetypes of Salmonella Typhimurium, in São Paulo, Brazil. Mem Inst Oswaldo Cruz. 2006;101:281-6.

24. Haneda T, Ishii Y, Shimizu H, Ohshima K, Iida N, Danbara H, et al. Salmonella type III effector $S p v C$, a phosphothreonine lyase, contributes to reduction in inflammatory response during intestinal phase of infection. Cell Microbiol. 2012;14:485-99.
25. Haneda T, Okada N, Nakazawa N, Kawakami T, Danbara H. Complete DNA sequence and comparative analysis of the 50-kilobase virulence plasmid of Salmonella enterica serovar Choleraesuis. Infect Immun. 2001;69:2612-20.

26. Hendriksen RS, Vieira AR, Karlsmose S, Lo Fo Wong DM, Jensen AB, Wegener HC et al. Global monitoring of Salmonella serovar distribution from the World Health Organization Global Foodborne Infections Network Country Data Bank: results of quality assured laboratories from 2001 to 2007. Foodborne Pathog Dis. 2011;8:887900 .

27. Herrero A, Rodicio MR, Echeita MA, Mendoza MC. Salmonella enterica serotype Typhimurium carrying hybrid virulence-resistance plasmids (pUO-StVR): a new multidrug-resistant group endemic in Spain. Int J Med Microbiol. 2008;298:253-61.

28. Hur J, Choi YY, Park JH, Jeon BW, Lee HS, Kim AR, et al. Antimicrobial resistance, virulence-associated genes, and pulsed-field gel electrophoresis profiles of Salmonella enterica subsp. enterica serovar Typhimurium isolated from piglets with diarrhea in Korea. Can J Vet Res. 2011;75:49-56.

29. Kich JD, Coldebella A, Morés N, Nogueira MG, Cardoso M, Fratamico PM, et al Prevalence, distribution, and molecular characterization of Salmonella recovered from swine finishing herds and a slaughter facility in Santa Catarina, Brazil. Int J Food Microbiol. 2011;151:307-13.

30. Lee KE, Jung JH, Jung BY, Park YH, Lee YH. Characterization of nalidixic acid-resistant and fluoroquinolone-reduced susceptible Salmonella Typhimurium in swine. J Food Prot. 2011;74:610-5

31. Liang N, Dong J, Luo L, Li Y. Detection of viable Salmonella in lettuce by propidium monoazide real-time PCR. J Food Sci. 2011;76:M234-7.

32. Little CL, Richardson JF, Owen RJ, De Pinna E, Threlfall EJ. Campylobacter and Salmonella in raw red meats in the United Kingdom: prevalence, characterization and antimicrobial resistance pattern, 2003-2005. Food Microbiol. 2008;25:538-43.

33. Lostroh CP, Lee CA. The Salmonella pathogenicity island-1 type III secretion system. Microbes Infect. 2001;3:1281-91.

34. Mazurkiewicz P, Thomas J, Thompson JA, Liu M, Arbibe L, Sansonetti P, et al. SpvC is a Salmonella effector with phosphothreonine lyase activity on host mitogen-activated protein kinases. Mol Microbiol. 2008;67:1371-83.

35. Meakins S, Fisher IS, Berghold C, Gerner-Smidt P, Tschäpe H, Cormican M, et al. Antimicrobial drug resistance in human nontyphoidal Salmonella isolates in Europe 2000-2004: a report from the Enter-net International Surveillance Network. Microb Drug Resist. 2008; 14:31-5

36. Medeiros MA, Oliveira DC, Rodrigues DP, Freitas DR. Prevalence and antimicrobial resistance of Salmonella in chicken carcasses at retail in 15 Brazilian cities. Rev Panam Salud Publica. 2011;30:555-60.

37. Mendoza M del C, Herrero A, Rodicio MR. Ingeniería evolutiva en Salmonella: la emergencia de plásmidos de virulencia-resistencia a antimicrobianos en sorotipos no tifoideos. Enferm Infecc Microbiol Clin. 2009;27:37-43.

38. Menezes GA, Khan MA, Harish BN, Parija SC, Goessens W, Vidyalakshmi K, et al. Molecular characterization of antimicrobial resistance in non-typhoidal salmonellae associated with systemic manifestations from India. J Med Microbiol. 2010;59:147783.

39. Molbak K. Human health consequences of antimicrobial drug-resistant Salmonella and other foodborne pathogens. Clin Infect Dis. 2005;41:1613-20.

40. Nde CW, Logue CM. Characterization of antimicrobial susceptibility and virulence genes of Salmonella serovars collected at a commercial turkey processing plant. J Appl Microbiol. 2008;104:215-23. 


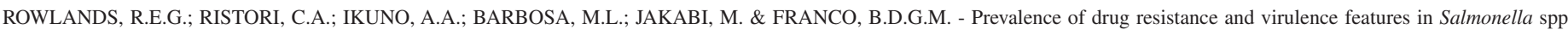
isolated from foods associated or not with salmonellosis in Brazil. Rev. Inst. Med. Trop. Sao Paulo, 56(6): 461-7, 2014.

41. Oliveira SD, Siqueira Flores F, Dos Santos LR, Brandelli A. Antimicrobial resistance in Salmonella Enteritidis strains isolated from broiler carcasses, food, human and poultry-related samples. Int J Food Microbiol. 2005;97:297-305.

42. Oliveira FA, Brandelli A, Tondo EC. Antimicrobial resistance in Salmonella Enteritidis from foods involved in human salmonellosis outbreaks in southern Brazil. New Microbiol. 2006;29:49-54.

43. Peirano G, Agerso Y, Aarestrup FM, Reis EM, Rodrigues DP. Occurrence of integrons and antimicrobial resistance genes among Salmonella enterica from Brazil. J Antimicrob Chemother. 2006;58:305-9.

44. Rychlik I, Gregorova D, Hradecka H. Distribution and function of plasmids in Salmonella enterica. Vet Microbiol. 2006;112:1-10.

45. Scallan E, Hoekstra RM, Angulo FJ, Tauxe RV, Widdowson MA, Roy SL, et al. Foodborne illness acquired in the United States-major pathogens. Emerg Infect Dis. 2011;17:715 .

46. SVS - Secretaria de Vigilância em Saúde. Dados epidemiológicos. Doenças transmitidas por alimentos (DTA) período de 2000-2011. Brasília: Ministério da Saúde; 2011. [cited 2012 Dec 10]. Available from: http://portal.saude.gov.br/portal/arquivos/pdf/ dados_epidemiologicos.pdf

47. Swamy SC, Barnhart HM, Lee MD, Dreesen DW. Virulence determinants invA and $s p v \mathrm{C}$ in salmonellae isolated from poultry products, wastewater, and human sources. Appl Environ Microbiol. 1996;62:3768-71.

48. Tamang MD, Nam HM, Kim A, Lee HS, Kim TS, Kim MJ, et al. Prevalence and mechanisms of quinolone resistance among selected nontyphoid Salmonella isolated from food animals and humans in Korea. Foodborne Pathog Dis. 2011;8:1199-206.

49. Valdez Y, Ferreira RB, Finlay BB. Molecular mechanisms of Salmonella virulence and host resistance. Curr Top Microbiol Immunol. 2009;337:93-127.

50. Valdezate S, Arroyo M, González-Sanz R, Ramíro R, Herrera-León S, Usera MA, et al. Antimicrobial resistance and phage and molecular typing of Salmonella strains isolated from food for human consumption in Spain. J Food Prot. 2007;70:2741-8.
51. Varma JK, Greene KD, Ovitt J, Barett TJ, Medalla F, Angulo FJ. Hospitalization and antimicrobial resistance in Salmonella outbreaks, 1984-2002. Emerg Infect Dis. 2005;11:943-6.

52. Vaz CS, Streck AF, Michael GB, Marks FS, Rodrigues DP, Dos Reis EM, et al. Antimicrobial resistance and subtyping of Salmonella enterica subspecies enterica serovar Enteritidis isolated from human outbreaks and poultry in southern Brazil. Poult Sci. 2010;89:1530-6.

53. Wannaprasat W, Padungtod P, Chuanchuen R. Class 1 integrons and virulence genes in Salmonella enterica isolates from pork and humans. Int J Antimicrob Agents. 2011;37:457-61.

54. WHO. World Health Organization. The evolving threat of antimicrobial resistance: options for action. Geneva: WHO; 2012. [cited 2012 Oct 04]. Available from: http:// whqlibdoc.who.int/publications/2012/9789241503181_eng.pdf

55. Woodring J, Srijan A, Puripunyakom P, Oransathid W, Wongstitwilairoong B, Mason C Prevalence and antimicrobial susceptibilities of Vibrio, Salmonella, and Aeromonas isolates from various uncooked seafoods in Thailand. J Food Prot. 2012;75:41-7.

56. Woodward MJ, Kirwan SE. Detection of Salmonella enteritidis in eggs by the polymerase chain reaction. Vet Rec. 1996;138:411-3.

57. Yan H, Li L, Alam MJ, Shinoda S, Miyoshi S, Shi L. Prevalence and antimicrobial resistance of Salmonella in retail foods in northern China. Int J Food Microbiol. 2010;143:230-4.

58. Zou M, Keelara S, Thakur S. Molecular characterization of Salmonella enterica serotype Enteritidis isolates from humans by antimicrobial resistance, virulence genes, and pulsed-field gel electrophoresis. Foodborne Pathog Dis. 2012;9:232-8.

Received: 23 October 2013

Accepted: 24 April 2014 